\title{
Body image satisfaction, nutritional status, anthropometric indicators and quality of life among the elderly
}

\author{
Renata Breda Martins ${ }^{1}$ \\ Raquel Rousselet Farias' \\ Douglas Nunes Stahnke' \\ Raquel Milani El Kik' \\ Carla Helena Augustin Schwanke ${ }^{2}$ \\ Thais de Lima Resende'
}

\section{Abstract}

Objective: to determine the prevalence of body image satisfaction in elderly subjects, as well as its relationship with nutritional status, anthropometric indicators and quality of life. Method: a cross-sectional, descriptive and analytical study was carried out with elderly individuals from Primary Care units (Family Health Strategy) from all the health districts of Porto Alegre, in the state of Rio Grande do Sul. The variables studied were: sociodemographic (gender; age; marital status and schooling), anthropometric (weight; height; body mass index; arm, calf, waist and hip circumference; waist-hip ratio and triceps skinfold), nutritional (Mini Nutritional Assessment), and clinical (quality of life; body image satisfaction). The Stunkard Silhouettes Scale, the Mini Nutritional Assessment and the Flanagan quality of life scale were applied. For data analysis, logistic regression (five steps) was performed with the Conditional Backward method. Results: a total of 532 elderly users (68.96 (7.14) years) were evaluated, mostly women $(64.8 \%)$ who were dissatisfied with their body image $(71.7 \%)$. The predictors of body image satisfaction were: eutrophic/underweight body mass index, eutrophy/insufficient arm circumference, and higher mean quality of life scores. Conclusion: in general, a low prevalence of body image satisfaction was identified among the elderly. Subjects with lower body mass index, smaller arm circumference measures and better quality of life had a greater chance of being satisfied with their body image.

\footnotetext{
Pontifícia Universidade Católica do Rio Grande do Sul, Escola de Ciências da Saúde. Porto Alegre, Rio Grande do Sul, Brasil.

2 Pontifícia Universidade Católica do Rio Grande do Sul, Escola de Medicina. Porto Alegre, Rio Grande do Sul, Brasil.

Funding: FAPERGS (Fundação de Amparo à Pesquisa do Rio Grande do Sul), edict 02/2009 PPSUS, process $n^{\circ} 09 / 0075-7$ and 09/0055-0.

Keywords: Body Image. Aged. Nutritional Status. Anthropometry. Quality of Life. 


\section{INTRODUCTION}

Body image corresponds to the mental representation of the body itself, experienced in an individual manner, including their senses, determining identity and thoughts, alluding to perceptions of personal feelings. However, it can be affected by the social environment with changes in interpersonal and behavioral relations ${ }^{2}$. Body image satisfaction is therefore constituted in a complex and multidimensional manner, based on several factors, including cultural, behavioral, sociodemographic, anthropometric and health related aspects ${ }^{1,2}$.

The physical and psychological aspects of aging can affect the perception of body image, as well as result in greater dissatisfaction due to changes in weight and metabolism. Furthermore, elderly women experience greater societal pressure regarding their physical appearance, which negatively impacts their experience of aging ${ }^{3}$.

In addition to questions related to body image, the elderly population is particularly prone to nutritional disorders due to physiological and social changes, the occurrence of chronic diseases, polypharmacy, sensory alterations, depression and changes in mobility with functional dependence ${ }^{4}$. The evaluation of nutritional status can be performed using different anthropometric indicators, to identify if there are disorders or a need for possible health interventions ${ }^{5}$.

Some studies have considered the influence of psychological and social aspects on the elderly, notably the perception of body image ${ }^{6,7}$. In addition, research related to the elderly and the aging process contemplates disease and the process of illness, rather than health itself $f^{4}$.

Nevertheless, more and more researchers from different areas are seeking to know more about and use quality of life in all its multidimensionality as a tool and instrument for measuring the impact of interventions and health services for the elderly ${ }^{8,9}$. Therefore, when evaluating the quality of life of the elderly, it is important to emphasize the importance of the use of heterogeneous evaluation criteria, which consider intersubjective aspects that occur more often in the elderly than in young adults, such as: diseases, loss of occupational roles and affective losses. The implications for the health and life potential of the elderly may alter interaction with the environment ${ }^{10}$.

Therefore, identifying the relationship that the elderly person maintains between their body image satisfaction and its implications for quality of life, nutritional status and anthropometric indicators is fundamental so that health professionals who work with this age group can better understand this issue and intervene in a more comprehensive manner ${ }^{1,11}$.

In light of the above, the present study aimed to determine the prevalence of body image satisfaction among the elderly, as well as its relationship with nutritional status, anthropometric indicators and quality of life.

\section{METHOD}

A cross-sectional study was performed with data obtained from the database generated by the research project entitled "Epidemiological and clinical study of the elderly treated by the Family Health Strategy of the city of Porto Alegre (EMISUS)", developed with a random sample of the elderly population, of both genders, registered with the Family Health Strategy (FHS) of Porto Alegre, in the state of Rio Grande do Sul (RS) ${ }^{12}$.

A total of 30 FHS teams were selected, stratified by district administrative unit, with around 30\% of the teams of each management unit selected. Data collection was carried out in three phases: (1) screening and general data collection through a home visit conducted by Community Health Agents, who interviewed the elderly persons and applied the questionnaire containing questions related to sociodemographic, economic and social aspects, morbidity and behaviors that interfere with health; (2) collection of laboratory tests (blood, faeces, urine) in the health unit, performed by members of the research group; (3) multidisciplinary evaluations carried out in the Hospital São Lucas (HSL) of the Pontifícia Universidade Católica do Rio Grande do Sul (PUCRS) relating to the clinical, nutritional and physical aspects of the elderly. The participants included the following professionals: physical educators, nurses, physiotherapists, geriatricians, neurologists, nutritionists, psychologists and psychiatrists, among others. The researchers were 
trained to apply the different instruments and the tests used to collect data ${ }^{12}$. Figure 1 shows the organizational chart of the study.

The data collection period was from March 2011 to December 2012. The criteria for inclusion in the survey were: age 60 years old or over and be registered with the FHS. Individuals unable to attend the multiprofessional evaluation were excluded ${ }^{12}$.
In this manner, the sociodemographic, clinical, anthropometric, nutritional and quality of life variables from the EMISUS database were analyzed. The description of the variables, their categorization, the evaluation instruments used and the collection sites are described in Chart 1, while the description of the instruments, the specific procedures of each measurement and the diagnostic criteria used are shown in Chart 2.

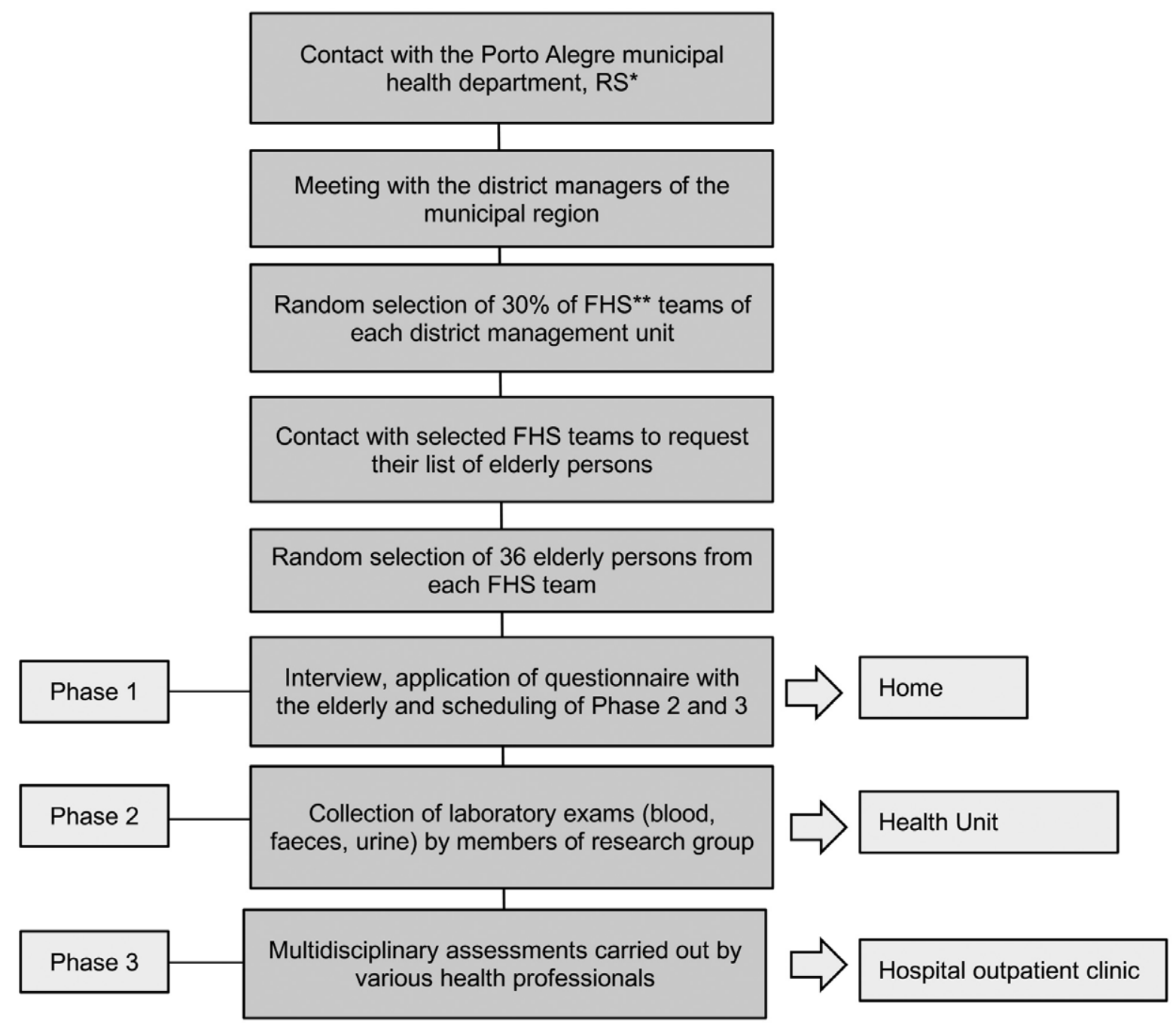

Figure 1. Flowchart of study. Porto Alegre, RS, 2018.

*Rio Grande do Sul; **Family Health Unit. 
Chart 1. Description of the variables presented, their categorization, evaluation instruments and collection sites. Porto Alegre, RS, 2018.

\begin{tabular}{|c|c|c|c|}
\hline \multirow[b]{2}{*}{ Variables } & \multirow[b]{2}{*}{ Categories } & \multicolumn{2}{|l|}{ Collection } \\
\hline & & Instrument & Local \\
\hline \multicolumn{4}{|l|}{ Sociodemographic } \\
\hline Age & $\mathrm{No}$ & OAQE & Home \\
\hline Age range & 60 to 69 years; 70 to 79 years; $\geq 80$ years & OAQE & Home \\
\hline Schooling & $\begin{array}{l}\text { Illiterate; low (1-8 years); medium (9-11 } \\
\text { years); high schooling ( }>11 \text { years) }\end{array}$ & OAQE & Home \\
\hline Marital status & $\begin{array}{l}\text { Lives with partner; doesn't live with } \\
\text { partner }\end{array}$ & OAQE & Home \\
\hline \multicolumn{4}{|c|}{ Anthropometric and nutritional } \\
\hline Weight $(\mathrm{kg})$ & No & Welmy Scale & HSL \\
\hline Height (m) & No & Metric tape & HSL \\
\hline BMI & $\begin{array}{l}\text { Underweight/thin }\left(22 \mathrm{~kg} / \mathrm{m}^{2}\right) ; \text { normal }(22- \\
\left.27 \mathrm{~kg} / \mathrm{m}^{2}\right) ; \text { overweight } / \text { obese }\left(27 \mathrm{~kg} / \mathrm{m}^{2}\right)\end{array}$ & $\begin{array}{l}\text { Quetelet }(\mathrm{BMI}= \\
\left.\text { weight/height }{ }^{2}\right)\end{array}$ & HSL \\
\hline $\mathrm{AC}$ & Age range/gender & Metric tape & HSL \\
\hline $\mathrm{CC}$ & $<31 \mathrm{~cm} ; \geq 31 \mathrm{~cm}$ & Metric tape & HSL \\
\hline TSF & Age range/gender & Cescorf Plicometer & HSL \\
\hline WHR & Men: $\geq 1.00 \mathrm{~cm}$; Women: $\geq 0.85 \mathrm{~cm}$ & Metric tape & HSL \\
\hline MNA & $\begin{array}{l}\text { malnutrition; nutritional risk; normal } \\
\text { nutritional state }\end{array}$ & $\begin{array}{l}\text { MNA } \\
\text { Questionnaire }\end{array}$ & HSL \\
\hline \multicolumn{4}{|l|}{ Clinical } \\
\hline Quality of life & $\begin{array}{l}\text { low ( } 7 \text { to } 45 \text { points); mean ( } 46 \text { to } 74 \text { points); } \\
\text { high (over } 75 \text { ) }\end{array}$ & $\begin{array}{l}\text { Flanagan Quality } \\
\text { of Life Scale }\end{array}$ & HSL \\
\hline Body image satisfaction & Yes; no & $\begin{array}{l}\text { Stunkard } \\
\text { Silhouettes Scale }\end{array}$ & HSL \\
\hline
\end{tabular}

OAQE: Overall Assessment Questionnaire for the Elderly; kg: kilogram; HSL: Hospital São Lucas da Pontifícia Universidade Católica do Rio Grande do Sul; kg: kilogram; m: meter; cm: centimeter; BMI: Body Mass Index; AC: Arm circumference; CC: Calf circumference; TSF: Triceps Skin Fold; WHR: Waist hip ratio; MNA: Mini Nutritional Assessment.

Chart 2. Description of instruments, specific procedures of each measurement and of the diagnostic criteria used for the collection of anthropometric and nutritional measures, body image satisfaction and quality of life. Porto Alegre, RS, 2018.

\begin{tabular}{|c|c|}
\hline Variables & Instruments/Diagnostic Criteria \\
\hline Weight & Mean $(\mathrm{kg})$ of Welmy scale with elderly person barefoot and not wearing accessories or adornments ${ }^{13}$. \\
\hline Height & $\begin{array}{l}\text { Measure }(\mathrm{m}) \text { with stadiometer coupled to the Welmy scale: standing erect in the orthostatic position } \\
\text { with the body fully extended and the head erect, looking forward with the feet together, and arms } \\
\text { extended alongside the body }{ }^{13} \text {. }\end{array}$ \\
\hline BMI & $\begin{array}{l}\text { Quetelet Index }=\text { Weight }(\mathrm{kg}) / \text { Height }\left(\mathrm{m}^{2}\right) \\
\text { The evaluation criteria were }{ }^{14}: \\
\text { - Low weight } / \text { thinness: } 22 \mathrm{~kg} / \mathrm{m}^{2} \\
\text { - Normal weight: between } 22 \mathrm{~kg} / \mathrm{m}^{2} \text { and } 27 \mathrm{~kg} / \mathrm{m}^{2} \\
\text { - Overweight/obesity: over } 27 \mathrm{~kg} / \mathrm{m}^{2}\end{array}$ \\
\hline $\mathrm{AC}$ & $\begin{array}{l}\text { Mean }(\mathrm{cm}) \text { of the midpoint between the acromion and the olecranon }{ }^{13} \text {. The values found were } \\
\text { classified as: inadequate }\left(\leq 25^{\text {th }} \text { percentile), normal }\left(>25^{\text {th }} \text { percentile and }<75^{\text {th }} \text { percentile }\right) \text { and }\right. \\
\text { excessive }\left(\geq 75^{\text {th }} \text { percentile }\right) \text {, distributed by gender and age }{ }^{15} \text {. }\end{array}$ \\
\hline WC & $\begin{array}{l}\text { Mean }(\mathrm{cm}) \text { at the furthest protruding point with the individual sitting and knee flexed at an angle of } 90^{\circ 16} \text {. } \\
\text { Absence of muscle loss was considered a WC equal to or greater than } 31 \mathrm{~cm} \text { for men and women }{ }^{17} \text {. }\end{array}$ \\
\hline
\end{tabular}


Continuation of Chart 2

\begin{tabular}{|c|c|}
\hline Variables & Instruments/Diagnostic Criteria \\
\hline Waist & Mean $(\mathrm{cm})$ at the height of the umbilical scar ${ }^{16}$. \\
\hline Hip & $\begin{array}{l}\text { Measured }(\mathrm{cm}) \text { at the level of the pubic symphysis with the tape circling the hip at the most } \\
\text { prominent point between the waist and thigh }{ }^{16} \text {. }\end{array}$ \\
\hline WHR & $\begin{array}{l}\text { Waist circumference }(\mathrm{cm}) / \text { hip circumference }(\mathrm{cm}) 16 \text {. } \\
\text { The classification used for cardiovascular risk was }{ }^{16} \text { : } \\
\text { - For women, WHR } \geq 0.85 \\
\text { - For men, WHR } \geq 1.00\end{array}$ \\
\hline TSF & $\begin{array}{l}\text { Measured }(\mathrm{mm}) \text { at the back of the arm, relaxed and extended alongside the body, marking the } \\
\text { midpoint between the acromion and the olecranon with the arm flexed close to the body, forming } \\
\text { an angle of } 90^{\circ 13} \text {. The values found were classified as: inadequate }(\leq 25 \text { th percentile), normal }(>25 \text { th } \\
\text { percentile and }<75 \text { th percentile) and excessive }\left(\geq 75 \text { th percentile), distributed by gender and age }{ }^{18} \text {. }\right.\end{array}$ \\
\hline MNA & $\begin{array}{l}\text { MNA Classification }{ }^{19}: \\
\text { - Malnutrition }<17 \text { points } \\
\text { - Risk of malnutrition } 17-23.5 \text { points } \\
\text { - Normal nutritional state } \geq 24 \text { points }\end{array}$ \\
\hline SBI & $\begin{array}{l}\text { Stunkard Silhouette Scale ranges from thinness (silhouette } 1 \text { ) to severe obesity (silhouette 9). The } \\
\text { elderly persons were asked to choose their real body appearance and that which they believed to be } \\
\text { the ideal appearance from the nine silhouettes presented. The SBI was determined by subtracting the } \\
\text { real body appearance from the ideal. If the result was zero, the individual was satisfied with his/her } \\
\text { body image, while any other score would indicate disbody image satisfaction }{ }^{20} \text {. }\end{array}$ \\
\hline Quality of life & $\begin{array}{l}\text { The minimum score of the Flanagan Quality of Life Scale is zero and the maximum is 105, which } \\
\text { allows quality of life to be classified into three levels }{ }^{21} \text { : } \\
\text { - Low ( } 7 \text { to } 45 \text { points) } \\
\text { - Mean ( } 46 \text { to } 74 \text { points) } \\
\text { - High (over } 75 \text { points) }\end{array}$ \\
\hline
\end{tabular}

kg: kilogram; m: meter; cm: centimeter; BMI: Body mass index; AC: arm circumference; CC: calf circumference; WHR: waist-hip ratio; TSF: triceps skinfold; mm: millimeter MNA: Mini Nutritional Assessment; SBI: body image satisfaction.

The sociodemographic variables analyzed were: age, age range, marital status and schooling. The anthropometric and nutritional variables were weight, height, Body Mass Index (BMI), arm circumference (AC), calf circumference (CC), triceps skin fold (TSF), waist circumference (WC), hip circumference (HC), waist/hip ratio (WHR) and the Mini Nutritional Assessment (MNA). The anthropometric measurements were all performed on the same day for each individual, on the right side of the body. The circumferences were obtained with a graduated, flexible and non-elastic measuring tape and the skin fold was measured with a Cescorf picometer.

The classification used for BMI was proposed by Lipschitz ${ }^{14}$, considering the changes in body composition that occur with aging, using three cutoff points: underweight $/$ thinness $\left(22 \mathrm{~kg} / \mathrm{m}^{2}\right)$; normal weight $\left(22-27 \mathrm{~kg} / \mathrm{m}^{2}\right)$; overweight/obese $\left(27 \mathrm{~kg} / \mathrm{m}^{2}\right)$.

The Stunkard ${ }^{20}$ scale was used to determine satisfaction or disbody image satisfaction, while the Flanagan scale was used for quality of life ${ }^{21}$.
The data were analyzed using the Statistical Package for Social Sciences version 20.0 (SPSS Inc., Chicago, IL, USA, 2008) program for Windows and a 5\% significance level was adopted. The study of data distribution of continuous variables was performed by the Kolmogorov-Smirnov test. For bivariate analysis between categorical variables, the Chi-squared test $\left(\chi^{2}\right)$ was used, where in the $2 \times 2$ contingency tables continuity correction was employed, with an estimate of the effect measure, the crude Odds Ratio (OR), with a confidence interval of $95 \%$ (CI95\%). Regarding the continuous variables, when the comparison occurred between two independent groups, the t-Student test was applied.

As the "body image satisfaction" outcome exhibited binary distribution, the Logistic Regression procedure was chosen for analysis, in which all the variables with values $p<0.200$ in the bivariate analysis were selected for multivariate analysis. The Backward conditional method was 
used based on the saturated model. The association was assessed with the likelihood-ratio test (2LL or $-2 \log$ ) and the quality of fit of the final model was evaluated with the Nagelkerk and HosmerLemeshow $\mathrm{R}^{2}$ estimators. The probability of gradual entry of the variables into the model was 0.05 , while for removal it was 0.10 . The significance of the cut-off point was 0.50 for the maximum of 20 interactions. Significance levels below 0.01 were considered significant based on the Bonferroni criterion.

The study was approved by the Research Ethics Committee of PUCRS (approval protocol: 10/04967) and the Municipal Health Department of the City of Porto Alegre (approval protocol: 001.021434.10.7), in compliance with Resolution $n^{\circ} 466 / 2012$ of the National Health Council.

\section{RESULTS}

The following results refer to a sample of 532 cases, after 55 of those surveyed (9.4\%) in the original database of 587 cases were discarded due to missing data on the primary outcome of the study, body image satisfaction. The mean age of the total sample was 68.96 (7.14) years, and $64.8 \%$ of the group were women $(n=345)$ while $35.2 \%$ were men $(n=187)$.

Table 1 shows the sociodemographic and quality of life characteristics of the sample, according to body image satisfaction. Only two variables presented representative relationships with body image satisfaction, gender and quality of life. Men were 2.5 times more likely to be satisfied with their body image than women, who were mostly dissatisfied with their body image (71.7\%), (Table 1).

Table 1. Socio-demographic characteristics and quality of life of the sample, according to body image satisfaction. Porto Alegre, RS, 2018.

\begin{tabular}{|c|c|c|c|c|c|}
\hline \multirow[t]{3}{*}{ Variables } & \multicolumn{5}{|c|}{ Body image satisfaction } \\
\hline & \multirow{2}{*}{ Yes $(n=165)$} & \multirow{2}{*}{ No $(n=367)$} & \multirow{2}{*}{$p^{*}$} & \multicolumn{2}{|c|}{ Gross odds ratio } \\
\hline & & & & OR & $\mathrm{CI} 95 \%$ \\
\hline Gender ${ }^{\dagger}$ & & & $<0.001^{\ddagger}$ & & \\
\hline Male & $83(50.3)$ & $104(28.3)$ & & 2.560 & $1.750-3.744$ \\
\hline Female & $82(49.7)$ & $263(71.7)$ & & 1.0 & \\
\hline \multicolumn{6}{|l|}{ Age (years) } \\
\hline Mean (SD) & $69.3( \pm 7.9)$ & $68.7( \pm 6.8)$ & & & \\
\hline Amplitude & $60.0-103.8$ & $58.0-95.0$ & $0.402^{\Im}$ & 1.011 & $0.986-1.037$ \\
\hline \multicolumn{6}{|l|}{ Age group ${ }^{\dagger}$} \\
\hline 60-69 years & $103(62.4)$ & $235(64.0)$ & $0.840^{\ddagger}$ & 1.0 & \\
\hline $70-79$ years & $47(28.5)$ & $104(28.3)$ & & 1.002 & $0.681-1.162$ \\
\hline$\geq 80$ years & $15(9.1)$ & $28(7.6)$ & & 1.056 & $0.841-1.155$ \\
\hline Marital status ${ }^{\dagger}$ & & & $0.216^{\ddagger}$ & & \\
\hline Lives with partner & $70(42.4)$ & $135(36.8)$ & & 1.266 & $0.871-1.842$ \\
\hline Does not live with partner & $95(57.6)$ & $232(63.2)$ & & 1.0 & \\
\hline Schooling $^{\dagger}$ & & & $0.213^{\ddagger}$ & & \\
\hline Illiterate/Low schooling & $147(89.1)$ & $339(92.4)$ & & 1.0 & \\
\hline Medium schooling & $18(10.9)$ & $28(7.6)$ & & 0.675 & $0.362-1.258$ \\
\hline High schooling & $0(0.0)$ & $0(0.0)$ & & & \\
\hline \multicolumn{6}{|l|}{ Quality of life } \\
\hline Mean (SD) & $88.9( \pm 10.6)$ & $85.4( \pm 10.6)$ & & & \\
\hline Amplitude & $33.0-105.0$ & $34.0-105.0$ & $0.002^{\|}$ & 1.03 & $1.01-1.05$ \\
\hline
\end{tabular}


The mean Flanagan score of individuals satisfied with their body image was significantly higher $(p=0.002)$ than those who were dissatisfied (Table 1), where the increase of one unit in quality of life score results in a 1.03 times greater body image satisfaction.

Table 2 shows the anthropometric characteristics and the nutritional status of the sample, according to body image satisfaction. Other factors associated with body image satisfaction were: underweight, greater height and lower BMI. Individuals classified as normal weight were 3.6 times more likely to be satisfied with their body image than obese individuals.

According to the results of Table 2, the satisfied with body image group had a significantly lower mean AC than the dissatisfied group. The group with inadequate $\mathrm{AC}$ had a 6.07 greater chance of being satisfied with body image than those with excessive AC. Similarly, cases with normal AC were 3.06 times more likely to be satisfied than the excessive AC group.

There was no statistically significant difference between the two groups in terms of WHR (Table 2). However, in the comparison between WHR scores, the group of individuals satisfied with body image was significantly associated with non-risk WHR, while those dissatisfied were associated with at risk WHR.

In CC comparison, the group dissatisfied with body image had a significantly higher mean [37.1 (3.8)] than those who were satisfied [35.8 (3.3)] (Table 2). However, no significant difference was detected in CC classifications, indicating that, in the present study, body image satisfaction is independent of CC classification.

In the evaluation of the TSF results, the mean was significantly higher among those dissatisfied with body image than among those who were satisfied (Table 2). In the comparison of body image satisfaction according to TSF classification, those with inadequate TSF had a 3.24 times greater chance and those with normal TSF a 2.54 times greater chance of being satisfied with body image than the group with excessive TSF.
The mean MNA of the satisfied with body image group was significantly higher than that of the dissatisfied group, with the former having a 1.60 times greater chance of being satisfied than the latter (Table 2). Evaluation of MNA classification did not reveal a significant difference, indicating similar behavior between the two groups.

Table 3 presents the Multivariate Binary Logistic Regression models for the prediction of body image satisfaction. The following variables were considered as potential predictors for the presence of body image satisfaction and therefore included in the initial logistic regression model: gender, BMI, classifications of AC, WHR and TSF; MNA classification; CC; and quality of life. Weight and height were no longer chosen for the model, as these data were included in the BMI.

According to the results of Table 3 , the (reduced) final model was achieved in five steps/stages, and, in addition to being significant, presented a representative quality of fit. Thus, based on the estimates presented, it was found that $37.2 \%$ of the variations that occurred in the odds ratio log were explained by the set of independent variables. With similar significance to the determination coefficient the Nagelkerke Test it was estimated that the model explained $39.7 \%$ of the variations observed for the presence of body image satisfaction.

Furthermore, in the model summary evaluation, the Hosmer and Lemeshow test indicated that there were no significant differences between the model estimates and the actual sample classifications for the presence of body image satisfaction. Thus, there is evidence that the (final) model presents a significant predictive capacity for the presence of body image satisfaction. The total was $76.3 \%$, where the model correctly classified $84.6 \%$ of cases that denied body image satisfaction, and $67.9 \%$ of cases that confirmed body image satisfaction.

According to the results obtained for the final model (Table 3), the predictors of body image satisfaction were: BMI of underweight or normal weight, inadequate and normal AC, and better quality of life. 
Table 2. Anthropometric characteristics and nutritional status of the sample, according to body image satisfaction. Porto Alegre, RS, 2018.

\begin{tabular}{|c|c|c|c|c|c|}
\hline \multirow[t]{3}{*}{ Variables } & \multicolumn{4}{|c|}{ Body image satisfaction } & \multirow[t]{2}{*}{ Gross Odds ratio } \\
\hline & Yes $(n=165)$ & & No $(n=367)$ & & \\
\hline & $\mathrm{N}$ & $\%$ & $\%$ & $\mathrm{p}$ & Risk (CI95\%) \\
\hline
\end{tabular}

\begin{tabular}{|c|c|c|c|c|}
\hline Mean (SD) [Amplitude] & $66.7( \pm 11.9)[36.9-96.8]$ & $71.8( \pm 14.5)[32.4-122.1]$ & $<0.001^{*}$ & $0.973(0.959-987)$ \\
\hline \multicolumn{5}{|l|}{ Height $(\mathrm{cm})$} \\
\hline Mean (SD) [Amplitude] & $1.59( \pm 0.09)[1.38-1.80]$ & $1.56( \pm 0.08)[1.32-1.78]$ & $0.001^{*}$ & $1.387(1.094-5.881)$ \\
\hline \multicolumn{5}{|l|}{$\operatorname{BMI}\left(\mathrm{kg} / \mathrm{m}^{2}\right)$} \\
\hline Mean (SD) [Amplitude] & $26.4( \pm 4.0)[17.7-48.1]$ & $29.6( \pm 5.7)[13.6-54.1]$ & $<0.001^{*}$ & $0.879(0.842-0.917)$ \\
\hline \multicolumn{5}{|l|}{ BMI Categories } \\
\hline Underweight & 9.6 & 7.3 & $<0.001^{\dagger}$ & $1.116(0.904-1.377)$ \\
\hline Normal weight & 54.8 & 25.6 & & $3.574(1.895-11.446)$ \\
\hline Underweight/obesity & 35.7 & 67.1 & & 1.0 \\
\hline
\end{tabular}

$\mathrm{AC}$

$\begin{array}{llllll}\text { Mean }(\mathrm{SD}) \text { [Amplitude] } & 30.3( \pm 3.5)[20.5-45.0] & 32.0( \pm 4.3)[17.5-29.4] & <0.001^{\ddagger} & 0.90(0.86-0.94) \\ \text { AC categories } & & & & <0.001^{\dagger} & \\ \text { Inadequate } & 71 & 43.3 & 86 & 23.6 & 6.07(3.01-12.29) \\ \text { Normal } & 82 & 50.0 & 197 & 54.1 & 3.06(1.55-6.05) \\ \text { Excessive } & 11 & 6.7 & 81 & 22.3 & 1.0\end{array}$

\begin{tabular}{|c|c|c|c|c|c|c|}
\hline \multicolumn{7}{|l|}{ WHR } \\
\hline Mean (SD) [Amplitude] & \multicolumn{2}{|c|}{$0.96( \pm 0.07)[0.75-1.14]$} & \multicolumn{2}{|c|}{$0.96( \pm 0.07)[0.72-0.91]$} & $0.527^{*}$ & $2.26(0.18-28.50)$ \\
\hline At risk & 113 & 73.4 & 293 & 84.2 & & 1.0 \\
\hline No risk & 41 & 26.6 & 55 & 15.8 & & $1.93(1.22-3.06)$ \\
\hline
\end{tabular}

\begin{tabular}{|c|c|c|c|c|c|c|}
\hline \multicolumn{7}{|l|}{$\mathrm{CC}$} \\
\hline Mean (SD) [Amplitude] & \multicolumn{2}{|c|}{$35.8( \pm 3.3)[26.8-46.6]$} & \multicolumn{2}{|c|}{$37.1( \pm 3.8)[25.0-48.1]$} & $<0.001^{*}$ & $0.91(0.86-0.96)$ \\
\hline \multicolumn{5}{|l|}{ CC categories } & \multicolumn{2}{|l|}{$0.720^{\dagger}$} \\
\hline Muscle loss & 6 & 3.7 & 16 & 4.4 & & 1.0 \\
\hline No muscle loss & 155 & 96.3 & 347 & 95.6 & & $1.19(0.45-3.10)$ \\
\hline \multicolumn{7}{|l|}{ TSF } \\
\hline Mean (SD) [Amplitude] & \multicolumn{2}{|l|}{$16.0( \pm 6.8)[4.0-42.0]$} & \multicolumn{2}{|c|}{$20.1( \pm 7.7)[4.0-45.0]$} & $<0.001^{*}$ & $0.27(0.90-0.95)$ \\
\hline TSF Categories & & & & & $0.002^{\dagger}$ & \\
\hline Inadequate & 68 & 42.0 & 117 & 32.1 & & $3.24(1.63-6.43)$ \\
\hline Normal & 82 & 50.6 & 180 & 49.5 & & $2.54(1.31-4.95)$ \\
\hline Excessive & 12 & 7.4 & 67 & 18.4 & & 1.0 \\
\hline
\end{tabular}

Total MNA score

\begin{tabular}{|c|c|}
\hline \multirow[t]{3}{*}{ Variables } & Body image satisf \\
\hline & Yes $(n=165)$ \\
\hline & $\mathrm{N}$ \\
\hline \multicolumn{2}{|l|}{ Weight (kg) } \\
\hline Mean (SD) [Amplitude] & $66.7( \pm 11.9)[36.9$ \\
\hline \multicolumn{2}{|l|}{ Height (cm) } \\
\hline Mean (SD) [Amplitude] & $1.59( \pm 0.09)[1.38$ \\
\hline \multicolumn{2}{|l|}{$\mathrm{BMI}\left(\mathrm{kg} / \mathrm{m}^{2}\right)$} \\
\hline Mean (SD) [Amplitude] & $26.4( \pm 4.0)[17.7-4$ \\
\hline \multicolumn{2}{|l|}{ BMI Categories } \\
\hline Underweight & 15 \\
\hline Normal weight & 86 \\
\hline Underweight/obesity & 56 \\
\hline \multicolumn{2}{|l|}{ AC } \\
\hline Mean (SD) [Amplitude] & $30.3( \pm 3.5)[20.5-4$ \\
\hline \multicolumn{2}{|l|}{ AC categories } \\
\hline Inadequate & 71 \\
\hline Normal & 82 \\
\hline Excessive & 11 \\
\hline \multicolumn{2}{|l|}{ WHR } \\
\hline Mean (SD) [Amplitude] & $0.96( \pm 0.07)[0.75$ \\
\hline \multicolumn{2}{|l|}{ WHR categories } \\
\hline At risk & 113 \\
\hline No risk & 41 \\
\hline \multicolumn{2}{|l|}{$\mathrm{CC}$} \\
\hline Mean (SD) [Amplitude] & $35.8( \pm 3.3)[26.8-4$ \\
\hline \multicolumn{2}{|l|}{ CC categories } \\
\hline Muscle loss & 6 \\
\hline No muscle loss & 155 \\
\hline \multicolumn{2}{|l|}{ TSF } \\
\hline Mean (SD) [Amplitude] & $16.0( \pm 6.8)[4.0-42$ \\
\hline \multicolumn{2}{|l|}{ TSF Categories } \\
\hline Inadequate & 68 \\
\hline Normal & 82 \\
\hline Excessive & 12 \\
\hline \multicolumn{2}{|l|}{ Total MNA score } \\
\hline Mean (SD) [Amplitude] & $26.1( \pm 2.9)[15.0-3$ \\
\hline
\end{tabular}

Mean (SD) [Amplitude] 26.1

$25.4( \pm 3.7)[9.0-30.0] \quad \begin{array}{ll}0.042^{\ddagger} \\ 0.107^{\dagger}\end{array} \quad 1.60(0.99-1.12)$

MNA Classification

\begin{tabular}{|c|c|c|c|c|c|}
\hline Normal & 121 & 81.2 & 251 & 74.5 & $1.32(0.93-1.89)$ \\
\hline Risk of malnutrition/ & 28 & 18.8 & 86 & 25.5 & 1.0 \\
\hline
\end{tabular}

malnutrition

n: sample size; p: statistical probability; CI95\%: Confidence interval 95\%; SD: mean standard deviation; BMI: body mass index; Underweight: BMI $<22 \mathrm{~kg} / \mathrm{m}^{2}$; Normal: BMI= 22-27kg $/ \mathrm{m}^{2} ;$ Overweight/obesity: BMI $>27 \mathrm{~kg} / \mathrm{m}^{2} ;$ AC: arm circumference; WH ratio: waist/hip ratio; CC: calf circumference; TSF: triceps skinfold; MNA: Mini Nutritional Assessment; *: Student t-test for independent groups assuming homogeneity of variance; †: Chi-squared test; ${ }^{\ddagger}:$ Student t-test for independent groups assuming heterogeneity of variance. 
Table 3. Models of Multivariate Binary Logistic Regression for the prediction of body image satisfaction. Porto Alegre, RS, 2018.

\begin{tabular}{|c|c|c|c|c|c|c|}
\hline \multirow[t]{4}{*}{ Independent variables } & \multicolumn{6}{|c|}{ Body image satisfaction } \\
\hline & \multicolumn{3}{|c|}{ Regression coefficient } & \multicolumn{3}{|c|}{ Adjusted Odds ratio } \\
\hline & \multirow[t]{2}{*}{ Gross } & \multirow[t]{2}{*}{ S.E. } & \multirow[t]{2}{*}{ Sig. } & \multirow[t]{2}{*}{$\operatorname{Exp}(B)$} & \multicolumn{2}{|l|}{$\mathrm{CI} 95 \%$} \\
\hline & & & & & Inferior & Superior \\
\hline \multicolumn{7}{|l|}{ Initial model } \\
\hline Male Gender & -0.317 & 0.453 & 0.484 & 0.728 & 0.300 & 1.769 \\
\hline \multicolumn{7}{|l|}{ BMI } \\
\hline Underweight $\left(\mathrm{BMI}<22 \mathrm{~kg} / \mathrm{m}^{2}\right)$ & 1.121 & 0.548 & 0.041 & 3.069 & 1.049 & 8.983 \\
\hline Normal weight $\left(\mathrm{BMI}=22-27 \mathrm{~kg} / \mathrm{m}^{2}\right)$ & 1.220 & 0.292 & 0.000 & 3.387 & 1.912 & 6.001 \\
\hline \multicolumn{7}{|l|}{ Arm circumference } \\
\hline Inadequate & 1.32 & 0.51 & 0.001 & 3.74 & 1.37 & 10.19 \\
\hline Normal & 0.65 & 0.42 & 0.133 & 1.92 & 0.84 & 4.39 \\
\hline \multicolumn{7}{|l|}{ Waist/hip ratio } \\
\hline No risk & 0.51 & 0.27 & 0.054 & 1.67 & 0.99 & 2.81 \\
\hline Calf circumference & -0.03 & 0.04 & 0.447 & 0.97 & 0.90 & 1.05 \\
\hline \multicolumn{7}{|l|}{ Triceps skinfold } \\
\hline Inadequate & 0.45 & 0.47 & 0.336 & 1.57 & 0.63 & 3.92 \\
\hline Normal & 0.52 & 0.43 & 0.228 & 1.68 & 0.72 & 3.91 \\
\hline \multicolumn{7}{|l|}{ MNA Classification } \\
\hline Normal & 0.392 & 0.244 & 0.108 & 1.48 & 0.92 & 2.39 \\
\hline Total MNA & 0.06 & 0.04 & 0.108 & 1.06 & 0.99 & 1.15 \\
\hline Quality of life & 0.03 & 0.01 & 0.035 & 1.03 & 1.00 & 1.05 \\
\hline \multicolumn{7}{|l|}{ Final model } \\
\hline \multicolumn{7}{|l|}{ BMI } \\
\hline Underweight $\left(\mathrm{BMI}<22 \mathrm{~kg} / \mathrm{m}^{2}\right)$ & 1.099 & 0.531 & 0.038 & 3.002 & 1.061 & 8.492 \\
\hline Normal $\left(\mathrm{BMI}=22-27 \mathrm{~kg} / \mathrm{m}^{2}\right)$ & 1.210 & 0.283 & 0.000 & 3.353 & 1.926 & 5.839 \\
\hline \multicolumn{7}{|l|}{ Arm circumference } \\
\hline Inadequate & 1.76 & 0.38 & $<0.001$ & 5.79 & 2.73 & 12.26 \\
\hline Normal & 0.97 & 0.37 & 0.001 & 2.64 & 1.28 & 5.43 \\
\hline Quality of life & 0.23 & 0.01 & 0.000 & 1.13 & 1.09 & 1.34 \\
\hline
\end{tabular}

\section{DISCUSSION}

The present study deals with important points in the context of research into the elderly, as it seeks to understand body image satisfaction, and its relationship with nutritional parameters, anthropometric measures, and quality of life. In addition, the analysis of the relationships of the various anthropometric indicators, especially those indicative of health risks, with body image satisfaction, in this age group, are presented in the literature in an incipient and unfocused manner regarding the reference standard used.

In general, a low prevalence of body image satisfaction $(31.0 \%)$ was identified in the public studied. A similar finding was found in another study of the elderly by Pereira et al. ${ }^{22}(27.4 \%)$, while 
Coradini et al. ${ }^{23}$ found an even lower prevalence $(12.5 \%)$. However, most studies reporting the prevalence of body image satisfaction ${ }^{2,22,23}$ present values of around one-third or less among the elderly investigated, as in the findings of the present study.

Menezes et al. ${ }^{2}$ reported that $56.4 \%$ of the 806 elderly people studied were satisfied with body image. It is possible that the difference between the findings of the present study and those of Menezes et al. ${ }^{2}$, both carried out with the Brazilian elderly and using the Stunkard Scale, is due to differences in income and schooling between the two samples, as well as climatic, geographical and cultural differences between the two regions where the studies were carried out, the northeast ${ }^{2}$ and the south, respectively.

Gomes et al. ${ }^{24}$, when evaluating 88 elderly people about body image satisfaction, concluded that despite the negative view of aging constructed by society, the sample studied exhibited a satisfactory experience of old age. However, there was dissatisfaction with body weight. A similar finding was found among the elderly in the present study, as $67.1 \%$ of those investigated who were dissatisfied with their body image had a BMI classified as overweight/obese, a finding that was particularly relevant among women, who comprised the majority of unsatisfied individuals $(71.7 \%)$, which is supported by studies that indicate that BMI in women is inversely related to satisfaction with body weight ${ }^{25,26}$. Nevertheless, obesity is more prevalent among women due to a greater accumulation of visceral and subcutaneous fat than among men $^{11}$, which contributes to dissatisfaction with appearance.

Another indication of the negative impact of excessive body weight on body image perception is the significant association between low/normal weight BMI and body image satisfaction, explained by the fact that normal weight elderly persons were 3.6 times more likely to be satisfied, a finding that remained relevant at the end of the logistic regression, after controlling for the many confounding variables. There is no consensus about this result, however, as Menezes et al. ${ }^{2}$, when evaluating 806 elderly residents in Campina Grande, Paraíba, observed that, among men and women, the chances of being dissatisfied with body image were similar among low weight and overweight/obese individuals, when compared with normal weight subjects. It is possible that different cultures and historical regional experiences explain such conflicting findings regarding body image dissatisfaction among the underweight elderly of both genders investigated by Menezes et al. ${ }^{2}$, in comparison with the present study.

In the present study $\mathrm{AC}$ also indicated that excessive weight negatively impacts body image satisfaction, as individuals in the inadequate/normal $\mathrm{AC}$ categories were significantly more likely to be satisfied, which is probably a reflection of lower body measurements, particularly considering the finding that those with poor AC had a 6.07 times greater chance of being satisfied. The relevance of AC for body image satisfaction was also detected by Pereira et al. ${ }^{22}$ in their study with elderly women who regularly performed aqua aerobics for five years or more. Nevertheless, the researchers indicated that WC was the measure most related to a good perception of body image, in which their findings differed from those of the present study, where WC was not a predictor of body image satisfaction.

These findings related to excessive weight support the reflection that, especially for women, when faced with aging, the corporal standards conveyed in the media, which favor a young, slim body, exert an influence. Despite the lesser influence of the media on male beauty patterns and the greater influence on female beauty patterns ${ }^{3,27}$, both men and women may present distortion in body image perception, either underestimating or overestimating their opinion of their bodies.

As important as nutritional status is the relationship the elderly persons maintain with their body and their quality of life, which, in the present study, was also found to be a relevant outcome and one of the predictors of body image satisfaction, as the better the quality of life scale score, the greater the chance of being satisfied. Like the present study, Skopinski et al. ${ }^{28}$ also found a better quality of life among those who were satisfied with their body image in a study of 46 postmenopausal women, most of whom were young. It was observed that the greater the disbody image satisfaction, the worse the quality of life perceived in the "physical", "psychological" and "environment" domains of the Whoqol-bref, another instrument that measures quality of life. 
The promotion of actions aimed at the well-being of the elderly and the improvement of public policies focused on this age group are required and must include an understanding of factors that influence body image satisfaction, as this is associated with better quality of life and aspects relevant to health, such as lower BMI and AC. Some evidence in literature indicates that increased BMI ends up being a predictive factor for disbody image satisfaction, and associates the obese elderly with greater dissatisfaction with their body image than those with normal weight and who were overweight ${ }^{29,30}$, with obesity associated with morbidity and mortality and the development of chronic non-communicable diseases $^{16,31}$.

One of the strengths of the present study is the representativeness of the sample, collected randomly from all the city's health districts, together with the use of a group of elderly people that are not represented in surveys in general, that is, elderly users of the FHS. Another strong point is the fact that this study also involved men, and in the same proportion as that found in the total elderly population of the studied municipal region ${ }^{32}$.

The main limitations of the present study are the lack of specific classifications of several of the anthropometric indicators for the elderly population, as well as the instrument used to evaluate body image satisfaction (Stunkard scale), which, despite being a classic method, does not have figures adapted for different age groups. Another perceived difficulty was the scarcity of recent studies with this subject and population, both in Brazilian and non-Brazilian literature, which made it difficult to compare the findings of the present study.

\section{CONCLUSION}

In general, a low prevalence of body image satisfaction was identified among the elderly. Those with lower body mass index, lower arm circumference measures and better quality of life were more likely to be satisfied with their body image.

The physical changes typical of aging are contrary to the demands of the media and society, which impose a stereotype of slimness and youth. It is fundamental to develop more actions aimed at the elderly, which include the understanding of aspects related to body image satisfaction.

Studies that aim to understand how the elderly perceive their body image and which factors influence this perception are therefore suggested. Instruments that use body images appropriate to this age group, which allow greater reliability in evaluation, are also required.

\section{REFERENCES}

1. Roy M, Payette H. The body image construct about western seniors: a systematic review of a literature. Arch Gerontol Geriatr. 2012;55(3):505-21.

2. Holland G, Tiggemann M. A systematic review of the impact of the use of social networking sites on body image and disordered eating outcomes. Body Image. 2016;17:100-10.

3. Hofmeier SM, Runfola CD, Sala M, Gagne DA, Brownley KA, Bulik CM. Body Image, aging, and identity in women over 50: the Gender and Body Image (GABI). Study J Women Aging. 2017;29(1):3-14.
4. World Health Organization. World report on ageing and health [Internet]. Luxembourg: WHO; 2015 [acesso em 15 dez. 2017]. Disponível em: http://apps.who.int/iris/ bitstream/10665/186463/1/9789240694811_eng.pdf

5. Sass A, Marcon SS. Comparação de medidas antropométricas de idosos residentes em área urbana no sul do Brasil, segundo sexo e faixa etária. Rev Bras Geriatr Gerontol. 2015;18(2):361-72.

6. Menezes TN, Brito KQD, Oliveira ECT, Pedraza DF. Percepção da imagem corporal e fatores associados em idosos residentes em município do nordeste brasileiro: um estudo populacional. Ciênc Saúde Colet. 2014;19(8):3451-60. 
7. Viana HB, Santos MR. Análise de percepção da imagem corporal e satisfação com a vida em idosos praticantes de hidroginástica. Rev Kairós. 2015;18(2):299-309.

8. Milte CM, Walker R, Luszcz MA, Lancsar E, Kaambwa B, Ratcliffe J. How important is health status in defining quality of life for older people?: an exploratory study of the views of older South Australians. Appl Health Econ Health Policy. 2014;12(1):73-84.

9. Makai P, Brouwer WBF, Koopmanschap MA, Stolk EA, Nieboer AP. Quality of life instruments for economic evaluations in health and social care for older people: a systematic review. Soc Sci Med. 2014;102:83-93.

10. Griffiths S, Hay P, Mitchison D, Mond JM, McLean SA, Rodgers B, et al. Sex differences in the relationships between body dissatisfaction, quality of life and psychological distress. Aust N Z J Public Health. 2016;40(6):518-22.

11. Liang X, Chen X, Li J, Yan M, Yang Y. Study on body composition and its correlation with obesity: A Cohort Study in 5121 Chinese Han participants. Medicine (Baltimore). 2018;97(21):1-6.

12. Gomes I, Nogueira EL, Engroff P, Ely LS, Schwanke CHA, De Carli GA, et al. The multidimensional study of the elderly in the family health strategy in Porto Alegre, Brazil (EMI-SUS). PAJAR. 2013;1(1):20-4.

13. National Center for Health Statistics. National Health and Nutrition Examination Survey: Anthropometry procedures manual [Internet]. Hyattsville: NCHS; 2009 [acesso em 04 out. 2016]. Disponível em: https://www.cdc.gov/nchs/data/nhanes/ nhanes_09_10/BodyMeasures_09.pdf

14. Lipschitz DA. Screening for nutritional status in the elderly. Prim Care. 1994;21(1):55-67.

15. Fryar CD, Gu Q, Ogden CL, Flegal KM. Anthropometric reference data for children and adults: United States, 2011-2014 [Internet]. Hyattsville: National Center for Health Statistics; 2016 [acesso em 04 out. 2016]. Disponível em: https://www.cdc.gov/ nchs/data/series/sr_03/sr03_039.pdf

16. World Health Organization. Obesity: preventing and managing the global epidemic. Geneva: Program of Nutrition, Family and Reproductive Health; 1998. (Technical Report Series no 894).

17. World Health Organization. Physical status: the use and interpretation of anthropometry: Report of the WHO Expert Committee. Geneva: World Health Organization; 1995. (Technical Report Series no 854).
18. Fryar CD, Gu Q, Ogden CL. Anthropometric reference data for children and adults: United States, 2007-2010 [Internet]. Hyattsville: National Center for Health Statistics; 2012 [acesso em 04 out. 2016]. Disponível em: https://www.cdc.gov/nchs/data/ series/sr_11/sr11_252.pdf

19. Vellas B, Garry PJ, Guigoz Y. Mini Nutritional Assessment (MNA): research and practice in the elderly. In: $1^{\circ}$ Nestle Clinical and Performance Nutrition Workshop, Mini Nutritional Assessment (MNA); October 1997; Lausane. Switzerland: Karger; 1999.

20. Scagliusi FB, Alvarenga M, Polacow VO, Cordás TA, Queiroz GKO, Coelho D, et al. Concurrent and discriminate validity of the Stunkard's figure rating scale adapted into Portuguese. Appetite. 2006;47(1):77-82.

21. Flanagan JC. Measurement of quality of life: current state of the art. Arch Phys Med Rehabil. 1982;63(2):56-9.

22. Pereira EF, Teixeira CS, Borgatto AF, Daronco LSE. Relação entre diferentes indicadores antropométricos e a percepção da imagem corporal em idosas ativas. Rev Psiquiatr Clín. 2009;36(2):54-9.

23. Coradini JG, Silva JR, Comparin KA, Loth EA, Kunz RI. Satisfação da imagem corporal e visão de idosas ativas sob a influência do exercício físico na sua autoimagem. Rev Kairós. 2012;15(3):67-80.

24. Gomes HM, Oliveira LB, Boas DTV, Lucena ALR, Vieira KFL, Freitas FFQF. Satisfação com imagem corporal: perspectiva de idosos inseridos em um grupo de convivência. Rev Ciênc Saúde Nova Esperança. 2014;12(2):71-9.

25. Ferreira AA, Menezes MFG, Tavares EL, Nunes NC, Souza FP, Albuquerque NAF, et al. Estado nutricional e autopercepção da imagem corporal de idosas de uma Universidade Aberta da Terceira Idade. Rev Bras Geriatr Gerontol. 2014;17(2):289-301.

26. Guedes MS, Cavalcanti Neto JL. Transtorno mental comum e imagem corporal de idosas do nordeste brasileiro. Estud Interdiscipl Envelhec. 2015;20(3):819-31.

27. Radwan H, Hasan HA, Najm L, Zaurub S, Jami F, Javadi F, et al. Eating disorders and body image concerns as influenced by family and media among university students in Sharjah, UAE. Asia Pac J Clin Nutr. 2018;27(3):695-700.

28. Skopinski F, Resende TL, Schneider RH. Imagem corporal, humor e qualidade de vida. Rev Bras Geriatr Gerontol. 2015;18(1):95-105. 
29. Román PAL, García-Pinillos F, Huertas Herrador JA, Cózar MB, Jiménez MM. Relationship between sex, body composition, gait speed and body satisfaction in elderly people. Nutr Hosp. 2014;30(4):851-57.

30. Marques RSA, Palma A, Assis M, Maranhão Neto GA. Insatisfação com a imagem corporal entre pessoas de meia-idade e idosas praticantes de atividade física. Estud Interdiscipl Envelhec. 2015;20(1):27-40.

Received: June 18, 2018

Reviewed: November 02, 2018

Accepted: December 07, 2018
31. Abdelaal M, le Roux CW, Docherty NG. Morbidity and mortality associated with obesity. Ann Transl Med. 2017;5(7):161.

32. Secretaria de Governança Local, Observatório da Cidade de Porto Alegre. População Idosa de Porto Alegre: Informação Demográfica e Socioeconômica [Internet]. Porto Alegre: Observa POA; 2015 [acesso em 03 dez. 2016]. Disponível em: http://lproweb. procempa.com.br/pmpa/prefpoa/observatorio/usu_ doc/informacao_demografica_e_socioeconomicapopulacao_idosa02.pdf 


\section{ERRATUM}

In the original article "Body image satisfaction, nutritional status, anthropometric indicators and quality of life among the elderly", published in Revista Brasileira de Geriatria e Gerontologia, v. 21, n. 6, p. 667-678, 2018, DOI: http://dx.doi.org/10.1590/1981-22562018021.180115

The corrected and complete text can be found in the link: https://www.rbgg.com.br/arquivos/edicoes/ RBGG_v21n6_ing.pdf

\section{On page 668, paragraph 1 , where it reads:}

"Body image satisfaction is therefore constituted..."

\section{Read:}

"Body image satisfaction is, therefore, constituted..."

\section{On page 668, paragraph 9, where it reads:}

"A total of 30 FHS teams were selected, stratified by health district administrative unit, with around 30\% of the teams of each management primary care health unit also randomly selected."

\section{Read:}

"A total of 30 FHS teams were randomly selected, stratified by health district, with around $30 \%$ of the teams of each primary care health unit also randomly selected." 
On page 669 , figure 1 , where it reads:

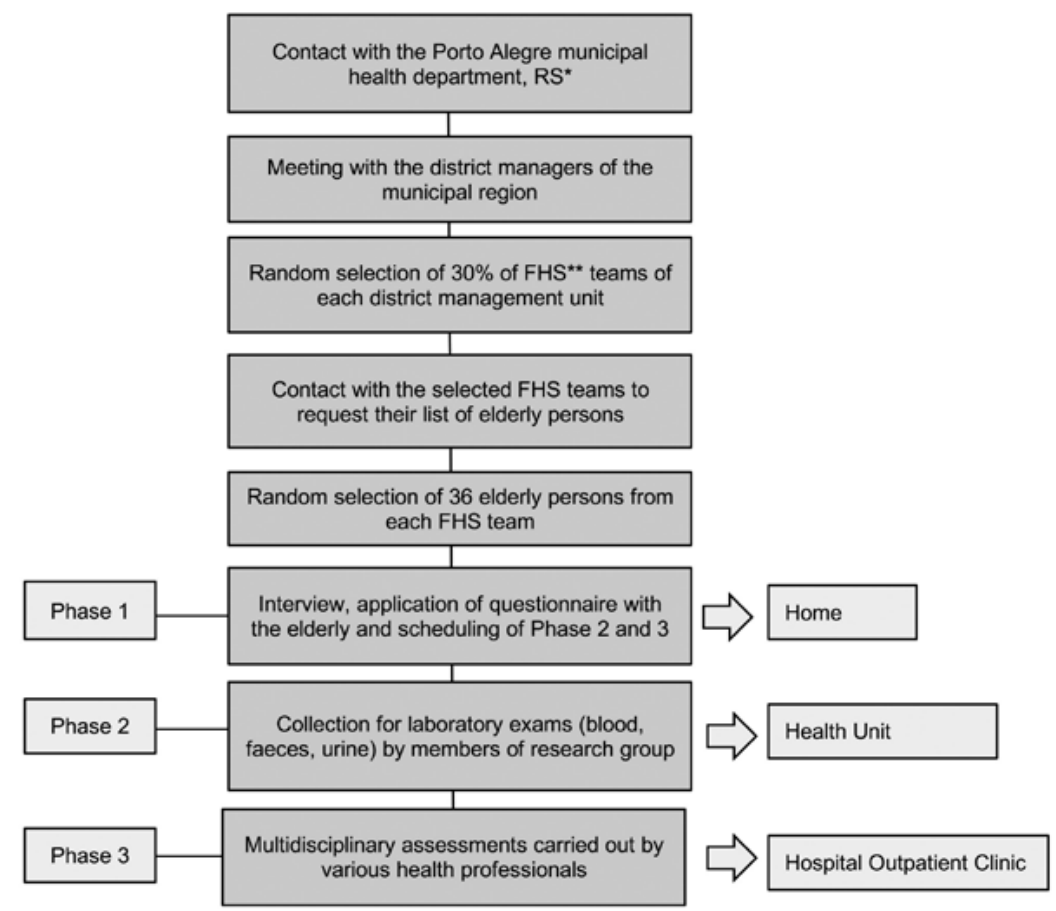

Figure 1. Flowchart of study, Porto Alegre, RS, 2018.

*Rio Grande do Sul; **Family Health Unit.

\section{Read:}

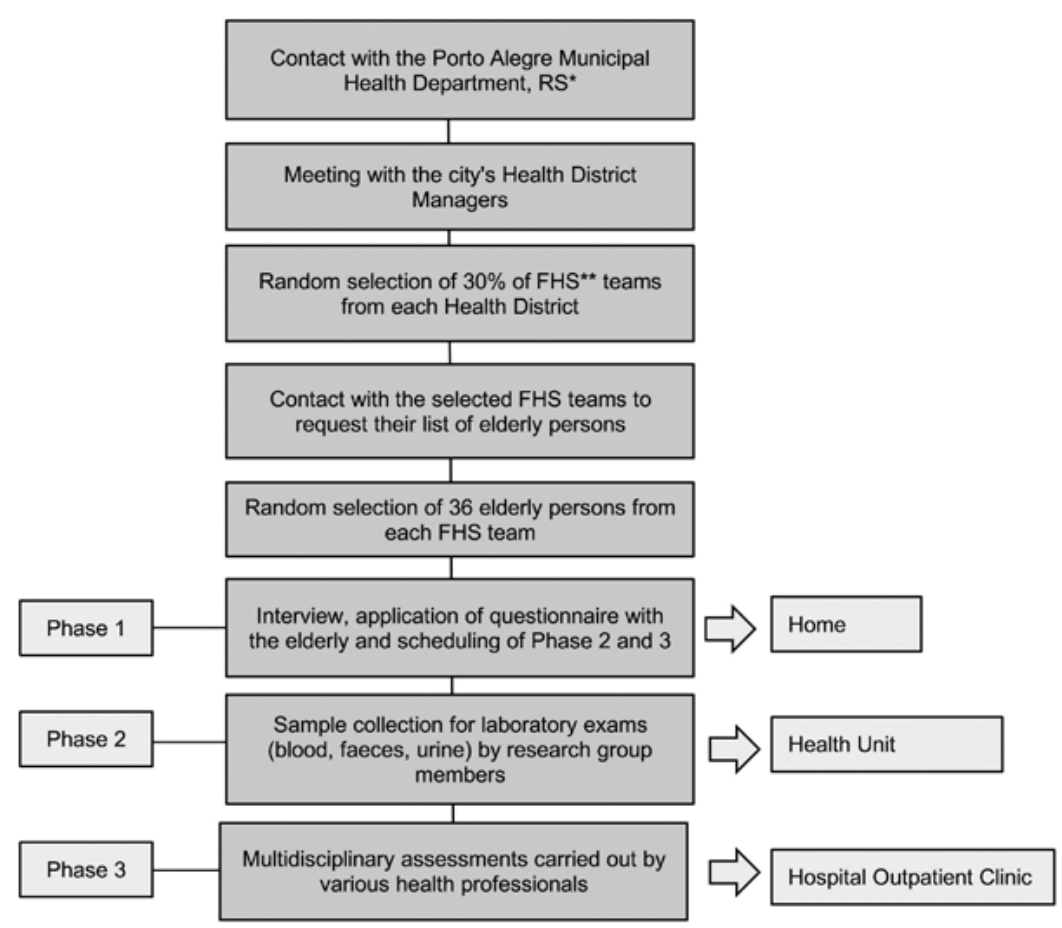

Figure 1. Flowchart of the study, Porto Alegre, RS, 2018.

*Rio Grande do Sul; **Family Health Unit. 
On page 670 , chat 1 , where it reads:

\begin{tabular}{|c|c|c|c|}
\hline \multirow[b]{2}{*}{ Variables } & \multirow[b]{2}{*}{ Categories } & \multicolumn{2}{|l|}{ Collection } \\
\hline & & Instrument & Local \\
\hline BMI & $\begin{array}{l}\text { Underweight } / \text { thin }\left(22 \mathrm{~kg} / \mathrm{m}^{2}\right) \text {; } \\
\text { normal }\left(22-27 \mathrm{~kg} / \mathrm{m}^{2}\right) ; \text { overweight/ } \\
\text { obese }\left(27 \mathrm{~kg} / \mathrm{m}^{2}\right)\end{array}$ & $\begin{array}{l}\text { Quetelet }(\mathrm{BMI}= \\
\left.\text { weight/height }{ }^{2}\right)\end{array}$ & HSL \\
\hline Body image satisfaction & Yes; no & $\begin{array}{l}\text { Stunkard } \\
\text { Silhouettes Scale }\end{array}$ & HSL \\
\hline
\end{tabular}

"OAQE: Overall Assessment Questionnaire for the Elderly; kg: kilogram; HSL: Hospital São Lucas da Pontifícia Universidade Católica do Rio Grande do Sul; kg: kilogram; m: meter; cm: centimeter; BMI: Body Mass Index; AC: Arm circumference; CC: Calf circumference; TSF: Triceps Skin Fold; WHR: Waist hip ratio; MNA: Mini Nutritional Assessment.”

\section{Read:}

\begin{tabular}{|l|l|l|l|}
\hline \multirow{2}{*}{ Variables } & Categories & Collection \\
\cline { 3 - 4 } BMI & $\begin{array}{l}\text { Underweight/thinness }(\leq 22 \mathrm{~kg} / \\
\left.\mathrm{m}^{2}\right) ; \text { normal weight }\left(>22-<27 \mathrm{~kg} / \mathrm{m}^{2}\right) ; \\
\text { overweight/obese }\left(\geq 27 \mathrm{~kg} / \mathrm{m}^{2}\right)\end{array}$ & $\begin{array}{l}\text { Quetelet }(\mathrm{BMI}= \\
\left.\text { weight } / \text { height }^{2}\right)\end{array}$ & HSL \\
\hline Body image satisfaction & yes/ no & $\begin{array}{l}\text { Stunkard } \\
\text { Silhouettes Scale }\end{array}$ & HSL \\
\hline
\end{tabular}

"OAQE: Overall Assessment Questionnaire for the Elderly; kg: kilogram; HSL: Hospital São Lucas da Pontifícia Universidade Católica do Rio Grande do Sul; m: meter; cm: centimeter; BMI: Body Mass Index; AC: Arm Circumference; CC: Calf Circumference; TSF: Triceps Skinfold; WHR: Waist-hip ratio; MNA: Mini Nutritional Assessment."

\section{On page 670-671, chart 2, where it reads:}

\begin{tabular}{|c|c|}
\hline Variables & Instruments/Diagnostic Criteria \\
\hline Weight & Mean $(\mathrm{kg})$ of Welmy scale with elderly person barefoot and not wearing accessories or adornments ${ }^{13}$. \\
\hline Height & $\begin{array}{l}\text { Measure }(\mathrm{m}) \text { with stadiometer coupled to the Welmy scale: standing erect in the orthostatic position } \\
\text { with the body fully extended and the head erect, looking forward with the feet together, and arms } \\
\text { extended alongside the body }{ }^{13} \text {. }\end{array}$ \\
\hline BMI & $\begin{array}{l}\text { Quetelet Index }=\text { Weight }(\mathrm{kg}) / \text { Height }\left(\mathrm{m}^{2}\right) \\
\text { The evaluation criteria were } \\
\text { - Low weight } / \text { thinness } 22 \mathrm{~kg} / \mathrm{m}^{2} \\
\text { - Normal weight: between } 22 \mathrm{~kg} / \mathrm{m}^{2} \text { and } 27 \mathrm{~kg} / \mathrm{m}^{2} \\
\text { - Overweight/obesity: over } 27 \mathrm{~kg} / \mathrm{m}^{2}\end{array}$ \\
\hline $\mathrm{AC}$ & $\begin{array}{l}\text { Mean }(\mathrm{cm}) \text { of the midpoint between the acromion and the olecranon }{ }^{13} \text {. The values found were } \\
\text { classified as: inadequate }\left(\leq 25^{\text {th }} \text { percentile), normal }\left(>25^{\text {th }} \text { percentile and }<75^{\text {th }} \text { percentile }\right) \text { and }\right. \\
\text { excessive }\left(\geq 75^{\text {th }} \text { percentile), distributed by gender and age } \mathrm{e}^{15} \text {. }\right.\end{array}$ \\
\hline WC & $\begin{array}{l}\text { Mean }(\mathrm{cm}) \text { at the furthest protruding point with the individual sitting and knee flexed at an angle of } 90^{\circ 16} \text {. } \\
\text { Absence of muscle loss was considered a WC equal to or greater than } 31 \mathrm{~cm} \text { for men and women }{ }^{17} \text {. }\end{array}$ \\
\hline Waist & Mean $(\mathrm{cm})$ at the height of the umbilical scar ${ }^{16}$. \\
\hline Hip & $\begin{array}{l}\text { Measured }(\mathrm{cm}) \text { at the level of the pubic symphysis with the tape circling the hip at the most } \\
\text { prominent point between the waist and thigh }{ }^{16} \text {. }\end{array}$ \\
\hline WHR & $\begin{array}{l}\text { Waist circumference }(\mathrm{cm}) / \text { hip circumference }(\mathrm{cm})^{16} \text {. } \\
\text { The classification used for cardiovascular risk } \text { was }^{16} \text { : } \\
\text { - For women, WHR } \geq 0.85 \\
\text { - For men, WHR } \geq 1.00\end{array}$ \\
\hline
\end{tabular}


Continuation of Chart 1

\begin{tabular}{|c|c|}
\hline TSF & $\begin{array}{l}\text { Measured }(\mathrm{mm}) \text { at the back of the arm, relaxed and extended alongside the body, marking the } \\
\text { midpoint between the acromion and the olecranon with the arm flexed close to the body, forming an } \\
\text { angle of } 90^{\circ 13} \text {. The values found were classified as: inadequate }(\leq 25 \text { th percentile), normal }(>25 \text { th } \\
\text { percentile and }<75 \text { th percentile) and excessive }\left(\geq 75 \text { th percentile), distributed by gender and age }{ }^{18} \text {. }\right.\end{array}$ \\
\hline MNA & $\begin{array}{l}\text { MNA Classification }^{19} \text { : } \\
\text { - Malnutrition }<17 \text { points } \\
\text { - Risk of malnutrition } 17-23.5 \text { points } \\
\text { - Normal nutritional state } \geq 24 \text { points }\end{array}$ \\
\hline SBI & $\begin{array}{l}\text { Stunkard Silhouette Scale ranges from thinness (silhouette 1) to severe obesity (silhouette 9). The } \\
\text { elderly persons were asked to choose their real body appearance and that which they believed to be } \\
\text { the ideal appearance from the nine silhouettes presented. The SBI was determined by subtracting the } \\
\text { real body appearance from the ideal. If the result was zero, the individual was satisfied with his/her } \\
\text { body image, while any other score would indicate dissatisfaction with body image }{ }^{20} \text {. }\end{array}$ \\
\hline $\begin{array}{l}\text { Quality of } \\
\text { life }\end{array}$ & $\begin{array}{l}\text { The minimum score of the Flanagan Quality of Life Scale is zero and the maximum is 105, which } \\
\text { allows quality of life to be classified into three levels }{ }^{21} \text { : } \\
\text { - Low ( } 7 \text { to } 45 \text { points) } \\
\text { - Mean ( } 46 \text { to } 74 \text { points) } \\
\text { - High (over } 75 \text { points) }\end{array}$ \\
\hline
\end{tabular}

kg: kilogram; m: meter; cm: centimeter; BMI: Body mass index; AC: arm circumference; CC: calf circumference; WHR: waist-hip ratio; TSF: triceps skinfold; mm: millimeter; MNA: Mini Nutritional Assessment; SBI: Body image satisfaction.

\section{Read:}

\begin{tabular}{|c|c|}
\hline Variables & Instruments/Diagnostic Criteria \\
\hline Weight & $\begin{array}{l}\text { Measured }(\mathrm{kg}) \text { in a Welmy scale with the elderly person barefoot and not wearing accessories or } \\
\text { adornments }^{13} \text {. }\end{array}$ \\
\hline Height & $\begin{array}{l}\text { Measured }(\mathrm{m}) \text { with the stadiometer coupled to the Welmy scale: standing erect in the orthostatic } \\
\text { position with the body fully extended and the head erect, looking forward with the feet together, and } \\
\text { arms extended alongside the body }{ }^{13} \text {. }\end{array}$ \\
\hline BMI & $\begin{array}{l}\text { Quetelet Index }=\text { Weight }(\mathrm{kg}) / \text { Height }\left(\mathrm{m}^{2}\right) \\
\text { The evaluation criteria were } \\
\text { - Under weight } / \text { thinness }\left(<22 \mathrm{~kg} / \mathrm{m}^{2}\right) \\
\text { - Normal weight }\left(>22--<27 \mathrm{~kg} / \mathrm{m}^{2}\right) \\
\text { - Overweight } / \text { obese }\left(>27 \mathrm{~kg} / \mathrm{m}^{2}\right)\end{array}$ \\
\hline $\mathrm{AC}$ & $\begin{array}{l}\text { Measurement }(\mathrm{cm}) \text { taken at the midpoint between the acromial process and the olecranon process }{ }^{13} \text {. } \\
\text { The values found were classified as: insufficient }\left(\leq 25^{\text {th }} \text { percentile), eutrophy }\left(>25^{\text {th }} \text { percentile and }\right.\right. \\
\left.<75^{\text {th }} \text { percentile }\right) \text { and excessive }\left(\geq 75^{\text {th }} \text { percentile), distributed by gender and age } e^{15} \text {. }\right.\end{array}$ \\
\hline $\mathrm{CC}$ & $\begin{array}{l}\text { Measured }(\mathrm{cm}) \text { at the furthest protruding point with the individual sitting and knee flexed at an angle } \\
\text { of } 90^{\circ 16} \text {. } \\
\text { Absence of muscle loss was considered a CC equal to or greater than } 31 \mathrm{~cm} \text { for men and women }{ }^{17} \text {. }\end{array}$ \\
\hline Waist & Measured $(\mathrm{cm})$ at the height of the umbilical scar ${ }^{16}$. \\
\hline Hip & $\begin{array}{l}\text { Measured }(\mathrm{cm}) \text { at the level of the pubic symphysis with the tape circling the hip at the most } \\
\text { prominent point between the waist and thigh }{ }^{16} \text {. }\end{array}$ \\
\hline WHR & $\begin{array}{l}\text { Waist circumference }(\mathrm{cm}) / \text { hip circumference }(\mathrm{cm})^{16} \text {. } \\
\text { The classification used for cardiovascular risk was }{ }^{16} \text { : } \\
\text { - For women, WHR } \geq 0.85 \\
\text { - For men, WHR } \geq 1.00\end{array}$ \\
\hline TSF & $\begin{array}{l}\text { Measured (mm) at the back of the arm, relaxed and extended alongside the body, marking the } \\
\text { midpoint between the acromion and the olecranon with the arm flexed close to the body, forming an } \\
\text { angle of } 90^{\circ 13} \text {. The values found were classified as: insufficient }(\leq 25 \text { th percentile), eutrophy }(>25 \text { th } \\
\text { percentile and }<75 \text { th percentile) and excessive ( } \geq 75 \text { th percentile), distributed by gender and age }{ }^{18} \text {. }\end{array}$ \\
\hline
\end{tabular}


Continuation of Chart 1

\begin{tabular}{|c|c|}
\hline MNA & $\begin{array}{l}\text { MNA Classification }{ }^{19}: \\
\text { - Malnutrition }<17 \text { points } \\
\text { - Risk of malnutrition } 17-23.5 \text { points } \\
\text { - Normal nutritional state } \geq 24 \text { points }\end{array}$ \\
\hline BIS & $\begin{array}{l}\text { Stunkard Silhouette Scale ranges from thinness (silhouette 1) to severe obesity (silhouette 9). The } \\
\text { elderly persons were asked to choose their real body appearance and that which they believed to be } \\
\text { the ideal appearance from the nine silhouettes presented. The BIS was determined by subtracting the } \\
\text { real body appearance from the ideal. If the result was zero, the individual was satisfied with his/her } \\
\text { body image, while any other score would indicate dissatisfaction with body image }{ }^{20} \text {. }\end{array}$ \\
\hline $\begin{array}{l}\text { Quality of } \\
\text { life }\end{array}$ & $\begin{array}{l}\text { The minimum score of the Flanagan Quality of Life Scale is zero and the maximum is 105, which } \\
\text { allows quality of life to be classified into three levels }{ }^{21} \text { : } \\
\text { - Low ( } 7 \text { to } 45 \text { points) } \\
\text { - Mean ( } 46 \text { to } 74 \text { points) } \\
\text { - High (over } 75 \text { points) }\end{array}$ \\
\hline
\end{tabular}

"kg: kilogram; m: meter; BMI: Body Mass Index; AC: Arm Circumference; CC: Calf Circumference; cm: centimeter; WHR: Waist-hip ratio; TSF: Triceps Skinfold; mm: millimeter MNA: Mini Nutritional Assessment; BIS: Body Image Satisfaction.”

\section{On page 671 , paragraph 1 , where it reads:}

"Waist/hip ratio (WHR)";

"Cescorf picometer."

\section{Read:}

"Waist-hip ratio (WHR)";

"Cescorf plicometer."

\section{On page 671, paragraph 2, where it reads:}

"underweight/thinness $\left(22 \mathrm{~kg} / \mathrm{m}^{2}\right)$; normal weight $\left(22-27 \mathrm{~kg} / \mathrm{m}^{2}\right)$; overweight $/$ obese $\left(27 \mathrm{~kg} / \mathrm{m}^{2}\right)$."

\section{Read:}

"underweight/thinness $\left(\leq 22 \mathrm{~kg} / \mathrm{m}^{2}\right)$; normal weight $\left(>22-<27 \mathrm{~kg} / \mathrm{m}^{2}\right)$; overweight/obese $\left(\geq 27 \mathrm{~kg} / \mathrm{m}^{2}\right)$."

\section{On page 671, paragraph 4, where it reads:}

"(CI95\%)";

"the t-Student test was applied".

\section{Read:}

"(95\% $\%$ CI )";

"the Student's T-test was applied". 


\section{On page 672, paragraph 3 , where it reads:}

"Only two variables presented representative relationships with body image satisfaction, gender and quality of life. Men were 2.5 times more likely to be satisfied with their body image than women, who were mostly dissatisfied with their body image (71.7\%), (Table 1)."

\section{Read:}

"Only two variables presented significant relationship with body image satisfaction - gender and quality of life. Men were 2.5 times more likely to be satisfied with their body image than women, who were mostly dissatisfied with their body image (71.7\%; Table 1)."

\section{On page 672, Table 1, where it reads:}

\section{"CI95\%";}

"OR: Odds Ratio; CI95\%: Confidence interval of 95\% for OR; SD: mean standard deviation; *: Minimum significance level for bivariate analysis; ${ }^{\dagger}$ : data presented as $\mathrm{n}(\%)$; ${ }^{\ddagger}$ : Chi-squared test; ${ }^{S}$ : T-Student test for independent groups assuming heterogeneity of variances; "I: T-Student test for independent groups assuming homogeneity of variences."

\section{Read:}

"95\%CI";

"OR: Odds Ratio; 95\%CI: 95\% Confidence Interval for OR; SD: standard deviation of the mean; *: Minimum significance level for bivariate analysis; ${ }^{\dagger}$ : data presented as $\mathrm{n}(\%)$; $:$ : Chi-squared test; ${ }^{\lessgtr}:$ Student's T-test for independent groups assuming heterogeneity of variances; "I: Student's T-test for independent groups assuming homogeneity of variances."

\section{On page 673, paragraph 1 , where it reads:}

“... one unit quality in of ..."

\section{Read:}

“... one unit quality in the of ..."

\section{On page 673 , paragraph 3 , where it reads:}

“...the satisfied with body image group had...";

“... inadequate AC ... with body image than those with excessive AC.”;

"Similarly, cases with normal AC..."

\section{Read:}

“...the group satisfied with their body image had..."

“...insufficient AC... with their body image than those with excessive AC.”; "Similarly, cases with eutrophic AC ..." 
On page 673 , paragraph 4 , where it reads:

“...with body image ...non-risk WHR, while those dissatisfied were associated with at risk WHR."

\section{Read:}

“...with their body image ...no-risk WHR, while those dissatisfied were associated with at-risk WHR.”

On page 673 , paragraph 5 , where it reads:

"...with body image..."

\section{Read:}

“...with their body image..."

On page 673 , paragraph 6 , where it reads:

"...with body image..."

\section{Read:}

"...with their body image..."

\section{On page 673, paragraph 7 , where it reads:}

“...with body image..."

“...inadequate TSF ...normal TSF ... with body image...”

\section{Read:}

“...whit their body image..."

“...insufficient TSF ...eutrophic TSF ... with their body image...”

\section{On page 673 , paragraph 8 , where it reads:}

"The mean MNA of the satisfied with body image group ... Evaluation of ..."

\section{Read:}

"The mean MNA of the group satisfied with their body image ... Evaluation of the ..."

\section{On Page 673, paragraph 9, where it reads:}

"... and therefore included..."

"... as these data ..."

\section{Read:}

“... and, therefore, included..."

“... as their data ..." 


\section{On page 673 , paragraph 11 , where it reads:}

"...inadequate and normal..."

\section{Read:}

"...insufficient and eutrophic..."

\section{On page 674 , Table 2 , where it reads:}

"(CI95\%)";

"Underweight/obesity";

"Inadequate";

"Normal";

"n: sample size; p: statistical probability; CI95\%: Confidence interval 95\%; SD: mean standard deviation; BMI: body mass index; Underweight: BMI $<22 \mathrm{~kg} / \mathrm{m}^{2}$; Normal: BMI $=22-27 \mathrm{~kg} / \mathrm{m}^{2}$; Overweight/obesity: BMI $>27 \mathrm{~kg} / \mathrm{m}^{2}$; AC: arm circumference; WH: waist $/$ hip ratio; CC: calf circumference; TSF: triceps skinfold; MNA: Mini Nutritional Assessment; *: Student t-test for independent groups assuming homogeneity of variance; †: Chi-squared test; ${ }^{\ddagger}:$ Student t-test for independent groups assuming heterogeneity of variance."

\section{Read:}

"(95\%CI)";

"Underweight/obese";

"Insufficient";

"Eutrophy";

"n: sample size; p: statistical probability; 95\%CI: 95\% Confidence Interval; SD: standard deviation of the mean; BMI: body mass index; Underweight/thinness: BMI $\leq 22 \mathrm{~kg} / \mathrm{m}^{2}$; Normal weight: BMI $>22-<27 \mathrm{~kg} / \mathrm{m}^{2}$; Overweight/obese: BMI $\geq 27 \mathrm{~kg} / \mathrm{m}^{2}$; AC: Arm Circumference; WHR: Waist-hip ratio; CC: Calf Circumference; TSF: Triceps Skinfold; MNA: Mini Nutritional Assessment; *: Student's t-test for independent groups assuming homogeneity of variance; ${ }^{\dagger}$ : Chi-squared test; ${ }^{\ddagger}:$ Student's t-test for independent groups assuming heterogeneity of variance."

\section{On page 675 , Table 3 , where it reads:}

"CI95\%";

"Underweight (BMI $\left.<22 \mathrm{~kg} / \mathrm{m}^{2}\right)$

Normal weight $\left(\right.$ BMI $\left.=22-27 \mathrm{~kg} / \mathrm{m}^{2}\right)$ ";

"Waist/hip";

"Inadequate

Normal";

"Normal";

"Underweight (BMI $\left.<22 \mathrm{~kg} / \mathrm{m}^{2}\right)$

Normal (BMI $\left.=22-27 \mathrm{~kg} / \mathrm{m}^{2}\right)$ "

"CI95\%: Confidence Interval 95\%; Gross: gross regression coefficient; S.E.: standard regression coefficient; Sig.: $p=$ minimum significance level for the regression coefficient; $\operatorname{Exp}(B)$ : Odds ratio; BMI: body mass 
index; MNA: Mini Nutritional Assessment. Initial Model - Score: Nalgelkerke R2 0.311; Hosmer-Lemeshow Test (Chi-squared test $=7.662 ; p=0.529)$; Cox \& Snell: 0.297; Overall hit ratio - confusion matrix: $62.9 \%$; OR: Odds ratio. Final Model - Score: Nalgelkerke R2 0.397; Hosmer-Lemeshow Test (Chi-squared test = 5.812; $p=0.449)$; Cox \& Snell: 0.372; Overall hit ratio - confusion matrix: 76.3\%; OR: Odds ratio."

\section{Read:}

"95\%CI";

"Underweight (BMI $\left.\leq 22 \mathrm{~kg} / \mathrm{m}^{2}\right)$

Normal weight (BMI $\left.>22->27 \mathrm{~kg} / \mathrm{m}^{2}\right)$ ";

"Waist-hip";

"Insufficient

Eutrophy";

"Normal Nutritional State";

"Underweight $\left(\mathrm{BMI} \leq 22 \mathrm{~kg} / \mathrm{m}^{2}\right)$

Normal weight (BMI $\left.>22-<27 \mathrm{~kg} / \mathrm{m}^{2}\right)$ "

"CI95\%: Confidence Interval 95\%; Gross: gross regression coefficient; S.E.: standard regression coefficient; Sig.: $p=$ minimum significance level for the regression coefficient; $\operatorname{Exp}(\mathrm{B})$ : Odds ratio; BMI: Body Mass Index; MNA: Mini Nutritional Assessment. Initial Model - Score: Nalgelkerke R2 0.311; Hosmer-Lemeshow Test (Chi-squared test $=7.662 ; p=0.529)$; Cox \& Snell: 0.297; Overall hit ratio - confusion matrix: $62.9 \%$; OR: Odds ratio. Final Model - Score: Nalgelkerke R2 0.397; Hosmer-Lemeshow Test (Chi-squared test = 5.812; $p=0.449)$; Cox \& Snell: 0.372; Overall hit ratio - confusion matrix: 76.3\%; OR: Odds ratio.”

\section{On page 675 , paragraph 1 , where it reads:}

"The present study deals with important points in the context of research into the elderly, as it seeks to understand body image satisfaction, and its relationship with nutritional parameters, anthropometric measures and quality of life. In addition, the analysis of the relationship of the various anthropometric indicators, especially those indicative of health risks, with body image satisfaction, in this age group, are presented in the literature in an incipient and unfocused manner regarding the reference standard used."

\section{Read:}

"The present study deals with relevant issues in the context of research into the elderly, as it seeks to understand body image satisfaction and its relationship with nutritional parameters, anthropometric measures and quality of life. In addition, In addition, in this age group, the analysis of the relationship among body image satisfaction and the various anthropometric indicators, especially those indicative of health risks, are presented in the literature in an incipient way and inconsistent with regards to the reference standard used."

\section{On page 675 , paragraph 2 , where it reads:}

“...public studied."

\section{Read:}

“...sample studied." 
On page 676, paragraph 1 , where it reads:

"...with the Brazilian..."

\section{Read:}

“...with Brazilian...”

\section{On page 676, paragraph 2, where it reads:}

“... when evaluating...”;

“... inversely related to satisfaction...";

"... to dissatisfaction with physical appearance."

\section{Read:}

“...investigating...”;

“... inversely related to the satisfaction...";

"... to dissatisfaction with the physical appearance."

\section{On page 676, paragraph 4, where it reads:}

“...inadequade/normal...with poor...”;

“...performed aqua aerobic...”;

"...WC..."

\section{Read:}

“...insufficient/eutrophy...whit insufficient...”;

“...performed aquatic exercise...”;

"...CC..."

\section{On page 676 , paragraph 5 , where it reads:}

“...especially for women, when faced with aging, the corporal standards conveyed in the media, which favor a young, slim body, exert an influence. Despite the lesser influence of the media on male beauty patterns and the greater influence on female beauty patterns ${ }^{3,27} \ldots "$

\section{Read:}

"...particularly among the women, and even in face of the aging process, there still is influence of the body standards portrayed in the media, which favor a young and slim body. Despite the lesser influence of the media on male beauty standards and its greater influence on female beauty standards $3,27 \ldots$..” 


\section{On page 676, paragraph 6, where it reads:}

"As important as nutritional status is the relationship the elderly persons maintain with their body and their quality of life, which, in the present study, was also found to be a relevant outcome and one of the predictors of body image satisfaction, as the better the quality of life scale score, the greater the chance of being satisfied. Like the present study, Skopinski et al. ${ }^{28}$ also found a better quality of life among those who were satisfied with their body image in a study of 46 postmenopausal women, most of whom were young. It was observed that the greater the disbody image satisfaction, the worse the quality of life perceived in the "physical", "psychological" and "environment" domains of the Whoqol-bref, another instrument that measures quality of life."

\section{Read:}

"The relationship that the elderly maintain with their body and their quality of life is as important as the nutritional status. In the present study, this relationship has been shown to be another relevant outcome and one of the predictors of satisfaction with body image, since the better the score on the quality of life scale, the greater the chance of being satisfied. As in the present study, Skopinski et al. ${ }^{28}$ also reported better quality of life among their subjects who were satisfied with their body image. The authors investigated 46 postmenopausal women, the majority of them were young old. They observed that the higher the dissatisfaction with body image, the worse the perceived quality of life in the "physical", "psychological" and "environment" domains of the WHOQOL-bref, another instrument that measures the quality of life ${ }^{28}$."

\section{On page 677, paragraph 1 , where it reads:}

"...body image satisfaction, as this is associated with better ... Some evidence in the literature indicates that increase in BMI ends up being a predictor factor for disbody image satisfaction, and associates the obese elderly whit greater dissatisfaction with their body image than those with normal weight and overweight ${ }^{29,30}$, with obesity associated with morbidity and mortality and the development of non-communicable diseases ${ }^{16,31}$."

\section{Read:}

“...body image satisfaction. The reason for the latter being its association with better quality of life and aspects relevant to health, such as lower BMI and AC. There is evidence in the literature that an increase in $\mathrm{BMI}$ is a predictor of body image dissatisfaction ${ }^{29,30}$. In addition, dissatisfaction with body image is more frequent in obese elderly than in those with normal weight and overweight ${ }^{29,30}$, with obesity associated with morbimortality and the development of non-transmissible chronic diseases ${ }^{16,31}$."

\section{On page 677, paragraph 2 , where it reads:}

“...studied municipal region ${ }^{32}$."

\section{Read:}

“...studied city ${ }^{32}, "$ 